\title{
ENZYME ACTIVITY AND MICROBIAL BIOMASS IN AN OXISOL AMENDED WITH SEWAGE SLUDGE CONTAMINATED WITH NICKEL
}

\author{
Marcos Donizeti Revoredo; Wanderley José de Melo* \\ ${ }^{1}$ UNESP/FCAV - Programa de Pós-Graduação em Produção Vegetal. \\ ${ }^{2}$ UNESP/FCAV - Depto. de Tecnologia, Via de Acesso Paulo Donato Castellane, s/n - 14884-900 - Jaboticabal, \\ SP - Brasil. \\ *Corresponding author 〈wjmelo@fcav.unesp.br>
}

\begin{abstract}
The role of nickel in soils of tropical areas under the application of sewage sludge is still not very well known. This study was carried out under greenhouse conditions in Jaboticabal, São Paulo State, Brazil, with the objective of evaluating the impact of the application of sewage sludge previously contaminated with rates of nickel $\left(329,502,746\right.$ and $1119 \mathrm{mg} \mathrm{kg}^{-1}$, dry basis) on a soil cropped with sorghum, in relation to soil enzyme activity and soil microbial biomass. Soil samples were collected at the beginning and the end of the experiment. The experimental design was completely randomized, with five treatments (control and four rates of $\mathrm{Ni}$ in the sewage sludge) and four replications. $\mathrm{C}$ and $\mathrm{N}$ of the soil microbial biomass and enzyme activities (acid and alkaline phosphatases) were sensitive indicators for impact evaluation caused by sewage sludge contaminated with nickel. There were positive correlations between "total" and extractable nickel (Mehlich 1) with $\mathrm{C}$-microbial biomass and negative with the microbial $\mathrm{C} / \mathrm{N}$ relationship. $\mathrm{N}$-microbial biomass correlated positively with "total" and extractable $\mathrm{Ni}$ at the last sampling. At the end of the experiment, the acid phosphatase activity correlated negatively with "total" $\mathrm{Ni}$ while the alkaline phosphatase correlated with both forms of the metal.
\end{abstract}

Key words: heavy metal, biosolid, acid phosphatase, alkaline phosphatase, sorghum

\section{ATIVIDADE ENZIMÁTICA E BIOMASSA MICROBIANA NUM LATOSSOLOTRATADO COM LODO DE ESGOTO CONTAMINADOCOMNÍQUEL}

\begin{abstract}
RESUMO: O comportamento do níquel em solos de regiões tropicais, principalmente quando adicionado através de lodos de esgoto, ainda é pouco conhecido. O estudo foi conduzido em casa de vegetação, localizada no município de Jaboticabal, Estado de São Paulo, Brasil, com o objetivo de avaliar o impacto da aplicação de lodo de esgoto contaminado com níquel $\left(329,502,746\right.$ e $1119 \mathrm{mg} \mathrm{kg}^{-1}$, base seca) sobre a atividade enzimática e a biomassa microbiana de um solo cultivado com sorgo. As amostras de solo foram coletadas em duas épocas (início e final do experimento). O delineamento utilizado foi o inteiramente casualizado, com cinco tratamentos (testemunha + quatro doses de $\mathrm{Ni}$ no lodo de esgoto) e quatro repetições. $\mathrm{O} \mathrm{C}$ e o $\mathrm{N}$ da biomassa microbiana e a atividade das fosfatases ácida e alcalina foram indicadores sensíveis na avaliação do impacto da aplicação do lodo de esgoto contaminado com níquel no solo. Houve correlação significativa e positiva entre os teores "totais" e extraíveis de Ni com o C da biomassa microbiana e negativa com a relação $\mathrm{C} / \mathrm{N}$ da biomassa microbiana nas duas épocas de amostragem. O N da biomassa microbiana correlacionou-se positivamente com os teores "totais" $\mathrm{e}$ extraíveis de Ni (Mehlich 1). A atividade da fosfatase ácida correlacionou-se negativamente com o Ni "total" e a atividade da fosfatase alcalina com os teores de Ni "total" e Ni extraível ao final do experimento. Palavras-chave: metal pesado, biossólido, fosfatase ácida, fosfatase alcalina, sorgo
\end{abstract}

\section{INTRODUCTION}

The total content of nickel in soil depends on the Ni content of the parent material and on the application of fertilizers, sewage sludge and atmospheric deposition (Alloway, 1995). Nickel accumulation in soil may be hazardous for plants, causing toxicity, and through them enter our food chain (Melo et al., 2004). Soil microorganisms have important functions in the soil, like synthesis and decomposition of organic matter and nutrient cycling. Soil enzyme activities are responsible for soil organic matter decomposition and are 
involved in the supply of nutrients to crops (Nannipieri, 1994). Soil enzyme activity is also sensitive to soil heavy metal pollution and it can therefore be used as a tool for monitoring modifications that occur in the soil environment caused by anthropogenic activities (Gianfreda \& Bollag, 1996). Moreno et al. (2003a) observed that phosphatase activity was the most sensitive soil enzyme to evaluate soil contamination by heavy metals. According to these authors, the other analyzed enzymes were in the following sequence: urease $>\beta$ glicosidase $>$ protease.

The objective of this study was to evaluate the effect of amending a Typic Haplustox with a pre-treated sewage sludge with increasing rates of $\mathrm{Ni}$ and cropping with sorghum, on soil microbial biomass and enzyme activity.

\section{MATERIAL AND METHODS}

The experiment was carried out under greenhouse conditions with controlled temperature (28 \pm $\left.5^{\circ} \mathrm{C}\right)$ at Jaboticabal, São Paulo, Brazil (21 ${ }^{\circ} 15^{\prime}$ S; $48^{\circ} 15^{\prime}$ $\mathrm{W}, 610 \mathrm{~m}$ above sea level). The soil was a Typic Haplustox collected from the top $0-20 \mathrm{~cm}$ soil layer presenting the following chemical properties (Raij et al., 1987): $\mathrm{pH}\left(0.01 \mathrm{M} \mathrm{CaCl}_{2}\right)=5.0, \mathrm{OM}=8 \mathrm{~g} \mathrm{dm}^{-3}, \mathrm{P}$ $\left(\right.$ resin) $=3 \mathrm{mg} \mathrm{dm}^{-3}, \mathrm{~K}=0.7 \mathrm{mmol}_{\mathrm{c}} \mathrm{dm}^{-3}, \mathrm{Ca}=12 \mathrm{mmol}_{\mathrm{c}}$ $\mathrm{dm}^{-3}, \mathrm{Mg}=4 \mathrm{mmol}_{\mathrm{c}} \mathrm{dm}^{-3}, \mathrm{H}+\mathrm{Al}=18 \mathrm{mmol}_{\mathrm{c}} \mathrm{dm}^{-3}, \mathrm{Sum}^{\mathrm{c}}$ of Bases $=17 \mathrm{mmol}_{\mathrm{c}} \mathrm{dm}^{-3}, \mathrm{CEC}=35 \mathrm{mmol}_{\mathrm{c}} \mathrm{dm}^{-3}$, Base Saturation $=48 \%$ and Nickel $=5.66 \mathrm{mg} \mathrm{kg}^{-1}$ (USEPA, 1986). Soil samples were air dried, sieved to $5 \mathrm{~mm}$ and split into 20 plots of $9.3 \mathrm{~kg}$ (capacity of each pot), each receiving $2.6 \mathrm{~g}$ of dolomitic limestone in order to raise the base saturation to about $70 \%$. After liming the soil was placed into polyethylene bags and incubated in the greenhouse for 30 days with moisture content of about $70 \%$ of the water retention capacity. After this period in which the soil $\mathrm{pH}$ changed to 5.8, the soil was removed from the bags, air dried, clods broken and sieved to $5 \mathrm{~mm}$.

Sewage sludge was obtained from the sewage sludge treatment plant located in Barueri, within the Great São Paulo city, and presented the following chemical composition: $\mathrm{N}=41 \mathrm{~g} \mathrm{~kg}^{-1}, \mathrm{P}=20 \mathrm{~g} \mathrm{~kg}^{-1}, \mathrm{~K}=$ $2 \mathrm{~g} \mathrm{~kg}^{-1}, \mathrm{Ca}=17 \mathrm{~g} \mathrm{~kg}^{-1}, \mathrm{Mg}=26 \mathrm{~g} \mathrm{~kg}^{-1}, \mathrm{~S}=4 \mathrm{~g} \mathrm{~kg}^{-1}$, $\mathrm{Cu}=694 \mathrm{mg} \mathrm{kg}^{-1}, \mathrm{Fe}=28 \mathrm{mg} \mathrm{kg}^{-1}, \mathrm{Mn}=198 \mathrm{mg} \mathrm{kg}^{-1}$, $\mathrm{Zn}=2.695 \mathrm{mg} \mathrm{kg}^{-1}$ and $\mathrm{Ni}=280 \mathrm{mg} \mathrm{kg}^{-1}$ (dry basis). Samples were air dried, crushed, sieved to $2 \mathrm{~mm}$ and split into the 16 plots of $0.5 \mathrm{~kg}$ (four Ni rates in the sewage sludge and four replications). To the four replicates of each treatment rates of $\mathrm{NiCl}_{2}$ were added so that the $\mathrm{Ni}$ added plus the $\mathrm{Ni}$ present in the sewage sludge gave concentrations of the heavy metal in the sewage sludge of 280, 420, 630 and $945 \mathrm{mg} \mathrm{kg}^{-1}$, dry basis (the treatment $280 \mathrm{mg} \mathrm{kg}^{-1}$ did not receive $\mathrm{NiCl}_{2}$ ). The nickel chloride was well mixed to the sewage sludge and each plot received water to $70 \%$ of the water retention capacity. Sewage sludge was then placed into polyethylene bags and incubated in the greenhouse for 60 days. Weekly the bags were vigorously shaken in order to obtain the maximum reaction between the residue and the $\mathrm{NiCl}_{2}$. After the period of incubation the sewage sludge of each bag was air dried, sieved to $2 \mathrm{~mm}$ and analyzed for "total" $\mathrm{Ni}$ content (USEPA, 1986). The pre-established rates of $\mathrm{Ni}$ in the different treatments were based on the CETESB (1999) limit of the metal concentration in sewage sludge for soil application, which is $420 \mathrm{mg} \mathrm{kg}^{-1}$ (dry basis).

The experiment was installed in a complete randomized experimental design with five treatments (control, without sewage sludge, and sewage sludge pre-treated with four rates of $\mathrm{Ni}$ ) and four replications.

The soil $(9.3 \mathrm{~kg})$ was placed into pots of 10 L capacity. At the beginning of the experiment, the control soil was fertilized with $1.4 \mathrm{~g} \mathrm{~N}$ (ammonium sulphate), $8.78 \mathrm{~g} \mathrm{P}_{2} \mathrm{O}_{5}$ (simple superphosphate) and $1.74 \mathrm{~g} \mathrm{~K}_{2} \mathrm{O}$ (potassium chloride). The other treatments received, per pot, $44.12 \mathrm{~g}$ of sewage sludge (equivalent to $10 \mathrm{Mg} \mathrm{ha}^{-1}$, dry weight basis) with the different concentrations of nickel to each treatment; $0.95 \mathrm{~g} \mathrm{~N}$ (ammonium sulphate), $2.25 \mathrm{~g} \mathrm{P}_{2} \mathrm{O}_{5}$ (simple superphosphate) and $1.31 \mathrm{~g} \mathrm{~K} O$ (potassium chloride). The mineral fertilizer quantities were applied to equalize the NPK content of the sewage sludge with that the control. All treatments also received $60 \mathrm{~mL}$ of a micronutrient solution $\left(57.6 \mathrm{mg} \mathrm{H}_{3} \mathrm{BO}_{3}, 118.2 \mathrm{mg}\right.$ $\mathrm{CuSO}_{4} .5 \mathrm{H}_{2} \mathrm{O}, 184.8 \mathrm{mg} \mathrm{MnSO}_{4} \cdot 4 \mathrm{H}_{2} \mathrm{O}, 5.4 \mathrm{mg}$ $\mathrm{NaMoO}_{4} \cdot 2 \mathrm{H}_{2} \mathrm{O}, 439.8 \mathrm{mg} \mathrm{ZnSO}$ and $18 \mathrm{~mL}$ of $\mathrm{Fe}$ EDTA solution, prepared with $0.45 \mathrm{~g} \mathrm{CuSO}_{4} \cdot 7 \mathrm{H}_{2} \mathrm{O}$, $0.60 \mathrm{~g}$ EDTA and $\left.1.44 \mathrm{~mL} 1 \mathrm{~mol} \mathrm{~L}^{-1} \mathrm{NaOH}\right)$ according to Melo et al. (1998). Distilled water was added to the soil to achieve $70 \%$ of the water capacity retention and sorghum was sown (10 seeds per pot of the hybrid Agroceres, IPUA/SP; Grain Sorghum, Family Safra CERTA). The sorghum was chosen as test plant since it can be cultivated in pots inside greenhouses until harvest and gives a good response to nickel (Melo et al., 1998). When plants were about $10 \mathrm{~cm}$ high, the excess of plants was removed, keeping the two best plants per plot. Sixty days after sowing plants were dress fertilized (7.0 g ammonium sulphate and $2.92 \mathrm{~g}$ potassium chloride per pot in the control; $4.71 \mathrm{~g}$ ammonium sulphate and $2.16 \mathrm{~g}$ de potassium chloride in the treatments that received sewage sludge).

Soil samples were taken from each pot soon after the experiment was installed ( 0 d.a.i. - days af- 
ter the experiment was installed) and after sorghum harvest (128 d.a.i.). The samples were obtained with a polyethylene tube $(2.5 \mathrm{~cm}$ diameter), collecting 3 simple samples from each pot, which were mixed to make a composite sample per pot. The samples for chemical analysis were air dried and sieved to $2 \mathrm{~mm}$. "Total" Ni was determined by atomic absorption spectrometry in the extract obtained by hot digestion with concentrated $\mathrm{HNO}_{3}, \mathrm{H}_{2} \mathrm{O}_{2}$ and $\mathrm{HCl}$ (USEPA, 1986). Extractable Ni was also evaluated by atomic absorption spectrometry, using the solution obtained by the Mehlich 1 extractor (Defelipo \& Ribeiro, 1981). The values of $\mathrm{pH}$ were obtained by potentiometry in 0.01 $\mathrm{M} \mathrm{CaCl}_{2}$ extracts, at a ratio of 1:5 w/v. Soil microbial biomass and enzyme activities were estimated on fresh samples immediately after sampling. Microbial biomass $\mathrm{C}$ and $\mathrm{N}$ were determined by the fumigation-extraction method (Vance et al., 1987). Soil urease activity was evaluated by the method proposed by May \& Douglas (1976) and the activities of phosphatases (acid and alkaline) were estimated by the method of Eivazi \& Tabatabai (1977).

The means of each treatment and each soil attribute were calculated and shown graphically with the respective cumulative standard errors. Correlation coefficients (r) between the "total" and extractable Ni contents with soil microbial biomass and enzyme activity were also calculated.

\section{RESULTS AND DISCUSSION}

During the period in which sewage sludge was incubated, some part of the Ni not determinated in the original sample was liberated, suggesting that probably the method USEPA (1986) did not achieve the determination of the real total content of $\mathrm{Ni}$ in the sewage sludge, so that the total $\mathrm{Ni}$ in different treatments were not 280, 420, 630 and 945, as intended, but really 329, 502, 746 and $1119 \mathrm{mg} \mathrm{kg}^{-1}$. Ni enrichments of sewage sludge did not affect soil $\mathrm{pH}$. It however decreased by about one unit at the end of the experiment (128 d.a.i., Figure 1). At the end of the experiment the soil $\mathrm{pH}$ was lower, which can be explained by plant growth and by the dislocation of $\mathrm{H}$ and $\mathrm{Al}$ from the colloidal complex, including $\mathrm{Ni}$.

With the decomposition of the sewage sludge in the soil during the experiment the extractable $\mathrm{Ni}$ increased. A positive correlation $(0.72 *)$ between extractable $\mathrm{Ni}$ and soil $\mathrm{pH}$ at the beginning of the experiment ( 0 d.a.i.) was found (Table 1$)$.

Sewage sludge contaminated with Ni increased "total" and extractable $\mathrm{Ni}$ in the soil at the two sampling times (Figure 2). The concentrations of these two forms of $\mathrm{Ni}$ were higher at the end of the experiment.

Microbial biomass-C increased with the application of sewage sludge contaminated with the different nickel levels in the samples obtained at the end of

Table 1 - Correlation coefficients (r) between soil contents of $\mathrm{Ni}$ (total and extractable) and soil enzyme activity, microbial biomass and $\mathrm{pH}$.

\begin{tabular}{|c|c|c|c|c|}
\hline & \multicolumn{4}{|c|}{$\mathrm{Ni}$ contents } \\
\hline & \multicolumn{2}{|c|}{0 d.a.i. } & \multicolumn{2}{|c|}{128 d.a.i. } \\
\hline & Total & Extractable & Total & Extractable \\
\hline & -- & -- & - & $-\ldots$ \\
\hline Urease & -0.30 & -0.39 & -0.34 & -0.31 \\
\hline Acid phosphatase & 0.05 & -0.11 & -0.25 & -0.04 \\
\hline Alkaline phosphatase & 0.29 & 0.16 & 0.17 & 0.21 \\
\hline Biomass- $\mathrm{C}^{\S}$ & -0.39 & $-0.63 *$ & $-0.76^{*}$ & $-0.81 *$ \\
\hline Biomass-N & 0.34 & 0.43 & 0.21 & 0.20 \\
\hline Biomass-C/N & -0.48 & $-0.72 *$ & $-0.67 *$ & $-0.71 *$ \\
\hline \multirow[t]{2}{*}{$\mathrm{pH}$} & $0.71 *$ & $0.72 *$ & $0.76^{*}$ & $0.86 *$ \\
\hline & -.--- & - n-n- & (n-n & - \\
\hline Urease & -0.38 & -0.26 & -0.07 & -0.02 \\
\hline Acid phosphatase & -0.24 & -0.33 & $-0.52 *$ & -0.39 \\
\hline Alkaline phosphatase & $-0.73 *$ & $-0.65^{*}$ & $-0.58 *$ & $-0.66^{*}$ \\
\hline Biomass- $\mathrm{C}^{\S}$ & $0.65 *$ & $0.75^{*}$ & $0.77 *$ & $0.86 *$ \\
\hline Biomass-N & $0.71 *$ & $0.76^{*}$ & $0.72 *$ & $0.77 *$ \\
\hline Biomass-C/N & $-0.82 *$ & $-0.83 *$ & $-0.76^{*}$ & $-0.81 *$ \\
\hline $\mathrm{pH}$ & 0.13 & 0.17 & 0.33 & 0.29 \\
\hline
\end{tabular}

${ }^{\mathrm{f}}$ d.a.i. = days after the experiment was installed. ${ }^{\circledR} \mathrm{C}, \mathrm{N}, \mathrm{C} / \mathrm{N}=$ microbial biomass carbon, nitrogen biomass carbon $\mathrm{C} / \mathrm{N}$ ratio in microbial biomass, respectively. ${ }^{*}$ Significant at $P<0.05$. 


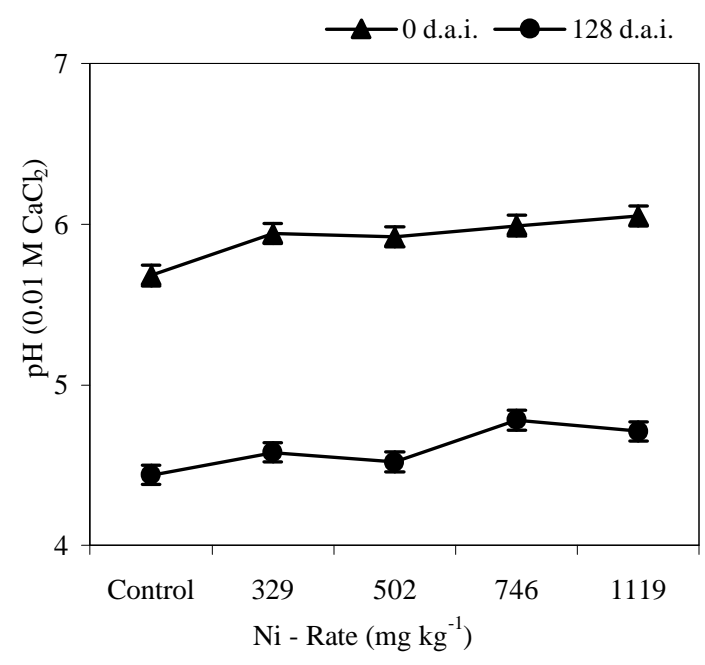

Figure 1 - Values of $\mathrm{pH}\left(0.01 \mathrm{M} \mathrm{CaCl}_{2}\right)$ in a Typic Haplustox (standard errors shown) submitted to five treatments (control plus four rates of Ni-sewage sludge) at 0 and 128 d.a.i. (days after the experiment was installed).
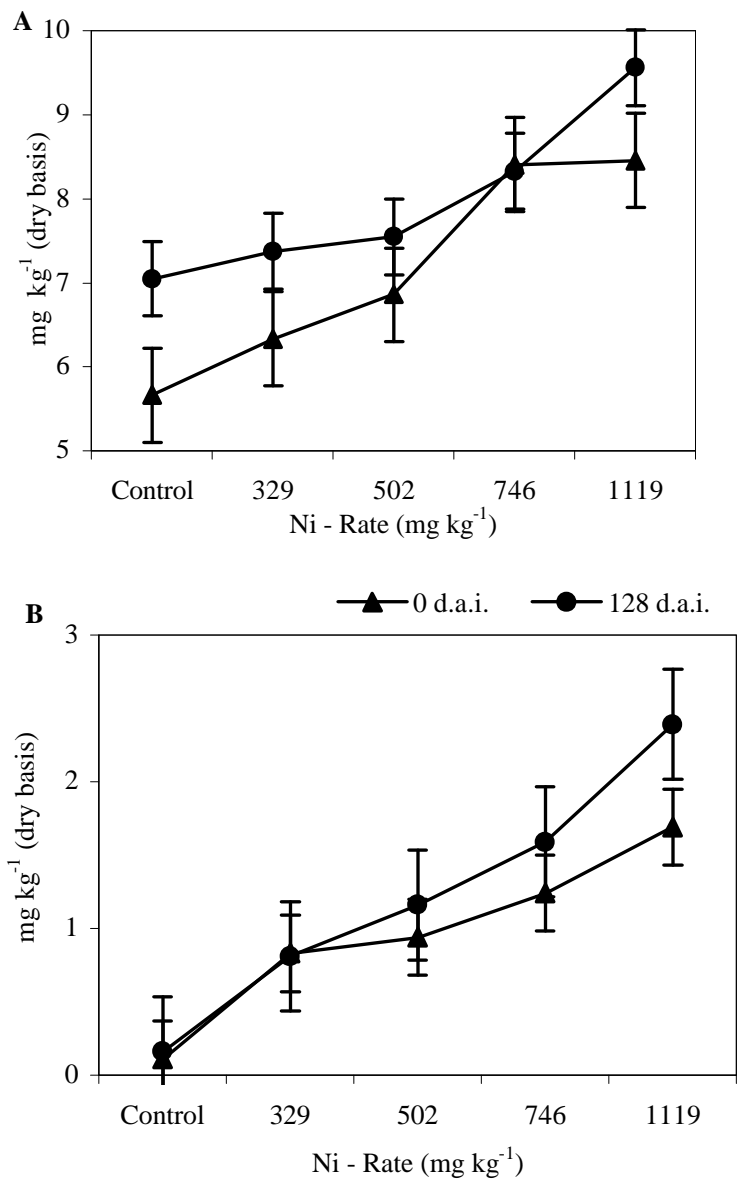

Figure 2 - "Total" (A) and extractable (Mehlich-1) Ni (B) in a Typic Haplustox (standard errors shown) submitted to five treatments (control plus four rates of $\mathrm{Ni}$ sewage sludge) at 0 and 128 d.a.i. (days after the experiment was installed). the experiment and decreased with the highest rate in the samples obtained soon after the sewage was added to the soil (Figure 3A). When organic residues are applied to a soil, microorganisms use the $\mathrm{C}$ bounds as energy source and the $\mathrm{C}$ for the production of microbial organic material, resulting an increase of biomass (Haider et al., 1991).

Microbial biomass-C decreased at the end of the experiment for all treatments (Figure 3A). "Total" $\mathrm{Ni}$ was higher in soil samples at the end of the experiment (except for the rate $746 \mathrm{mg} \mathrm{kg}^{-1}$ ) while the extractable $\mathrm{Ni}$ was higher in the treatments in which $\mathrm{NiCl}_{2}$ was added to the sewage sludge. This decrease in microbial biomass- $\mathrm{C}$ may have been caused by an increase in the concentration of toxic elements during incubation. At the start of the experiment, the highest rate of $\mathrm{Ni}$ caused a decrease of this soil attribute, which was not observed at the final sampling. Similarly, Moreno et al. (2003b) reported a decrease in soil microbial biomass- $\mathrm{C}$ for the treatments that had received higher rates of Ni. Similar results were also reported by Kupermam \& Carreiro (1997) in a contaminated grassland ecosystem. The response of soil microorganisms to an increase in the heavy metal concentration is complex and cannot be totally explained by a single rate-answer relation (Welp \& Brümmer, 1997). However, Chander and Brookes (1993), investigating the effects of heavy metal enriched sludges observed that $\mathrm{Ni}$ alone or a combination of $\mathrm{Ni}$ (maximum of $53 \mathrm{mg} \mathrm{kg}^{-1}$ soil) with low concentrations of Zn did not show any adverse effects on soil microbial biomass in soils of England. Chander et al. (1995) working with metal-enriched sewage sludges also found that the total $\mathrm{Ni}$ concentration in a soil (Eutric Cambisol) at about the level of the currently permitted limits $\left(75 \mathrm{mg} \mathrm{kg}^{-1}\right.$ soil) did not decrease the amounts of microbial biomass-C. A negative correlation between microbial biomass-C with "total" (USEPA, 1986) and extractable Ni (Mehlich 1) was found at the beginning of the experiment and negative at the end (Table 1).

Soil microbial biomass-N was not affected by the treatments for the first sampling (Figure 3B). At the final sampling, the lowest value was observed for the lowest rate of $\mathrm{Ni}$, which was lower than the control, while for the highest rates of $\mathrm{Ni}$ the microbial biomass-N was similar to the control. At the end of the experiment, microbial biomass- $\mathrm{N}$ decreased for the treatments that received sewage sludge and did not receive $\mathrm{NiCl}_{2}$ or that received low rates of the contaminant, showing that toxic products were liberated during the experimental period and that $\mathrm{Ni}$ improved $\mathrm{N}$ assimilation by the microorganisms, probably by a positive effect on enzyme activity as urease (Malavolta 

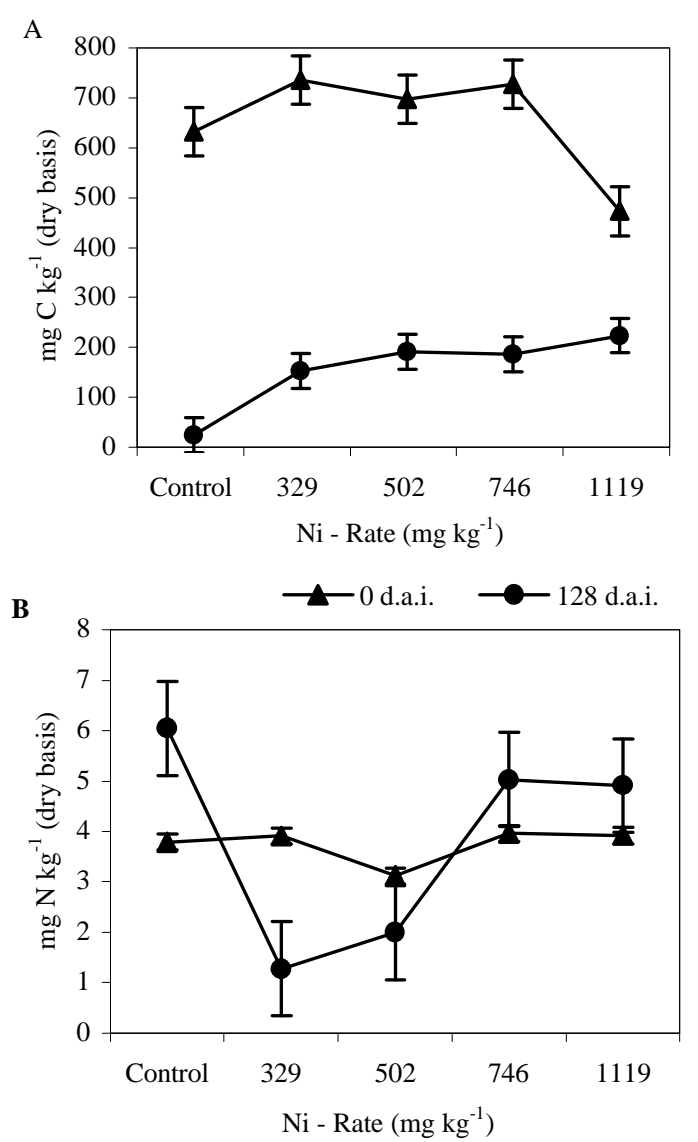

Figure 3 - Microbial biomass C (A) and N (B) in a Typic Haplustox (standard errors shown) submitted to five treatments (control plus four rates of Ni-sewage sludge) at 0 and 128 d.a.i. (days after the experiment was installed).

et al., 2006). A positive correlation was found between microbial biomass-N with "total" and extractable $\mathrm{Ni}$ (Table 1).

The microbial biomass $\mathrm{C} / \mathrm{N}$ ratio presented peaks of values at the two sampling times (Figure 4). At the beginning, the peak was determined by the rate $746 \mathrm{mg} \mathrm{kg}^{-1} \mathrm{Ni}$, while at the end the peak was determined by the rate $502 \mathrm{mg} \mathrm{kg}^{-1} \mathrm{Ni}$. At the end of the experiment, that relationship was lower for all treatments, showing that soil microorganisms needed more $\mathrm{C}$ than $\mathrm{N}$ for maintaining their metabolism, confirming that under stress conditions, in this case caused by the liberation of toxic elements from the sewage sludge, the consumption of $\mathrm{C}$ is increased. A positive correlation between microbial biomass- $\mathrm{C} / \mathrm{N}$ and "total" and extractable $\mathrm{Ni}$ was found at the two sampling times (Table 1).

At the first sampling, the urease activity (Figure 5) increased when $\mathrm{NiCl}_{2}$ was added to the sewage sludge, but decreased at the highest concentrations of the salt. At the second sampling, urease activity showed a light increase in activity with Ni concentration, which

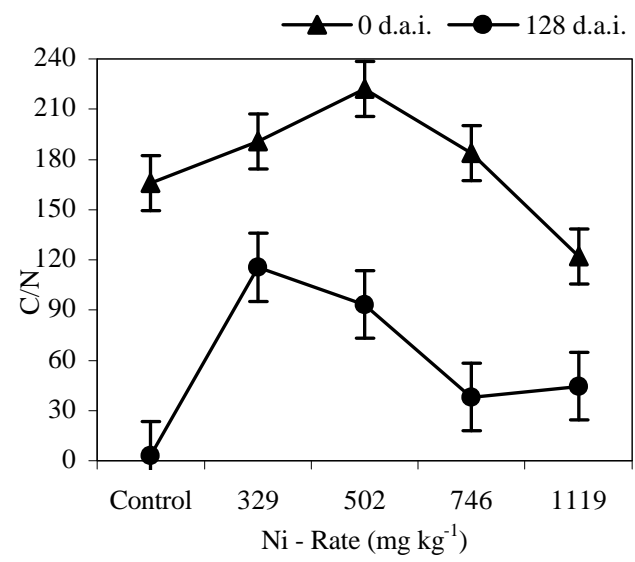

Figure 4 - Microbial biomass $\mathrm{C} / \mathrm{N}$ relationship in a Typic Haplustox (standard errors shown) submitted to five treatments (control plus four rates of $\mathrm{Ni}$-sewage sludge) at 0 and 128 d.a.i. (days after the experiment was installed).

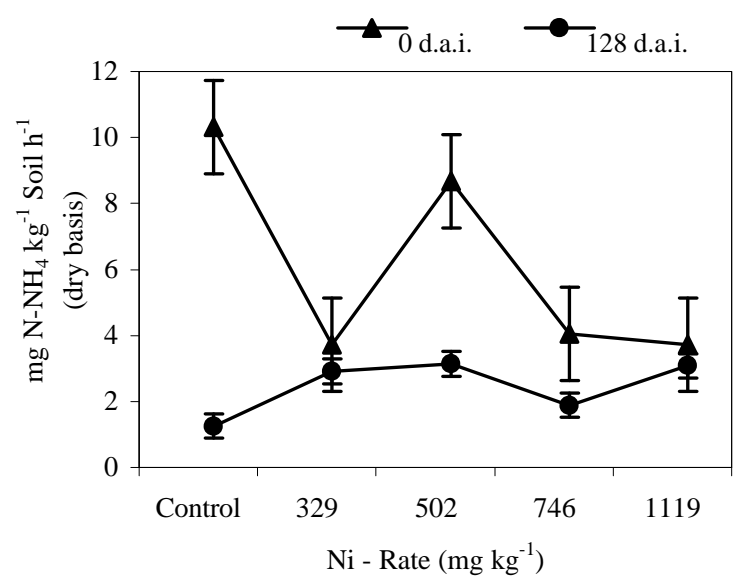

Figure 5 - Urease activity in a Typic Haplustox (standard errors shown) submitted to five treatments (control plus four rates of $\mathrm{Ni}$-sewage sludge) at 0 and 128 d.a.i. (days after the experiment was installed).

may be due to the enzyme activation, once $\mathrm{Ni}$ is a component of the active site (Malavolta et al., 2006). The enzyme activity did not correlate with total or extractable Ni (Table 1). Moreno et al. (2003a) also found that urease activity decreased as a function of the time, and that the enzyme activity decreased when Ni concentration in the soil increased. For this soil, urease activity was not a good indicator of the impact caused by the presence of Ni. Similarly, Carneiro et al. (2003) reported that the contamination with heavy metals provoked a severe decrease in microbial biomass, acid phosphatase and urease activity.

Sewage sludge contaminated with the lowest rate of $\mathrm{NiCl}_{2}$ caused an increase in the acid phosphatase activity at the first sampling, while the highest rates caused a decrease (Figures 6A). At the end 
of the experiment, all the rates of $\mathrm{NiCl}_{2}$ caused decrease in acid phosphatase activity. Considering that "total" and extractable $\mathrm{Ni}$ were higher at the end of the experiment when sewage sludge was contaminated with $\mathrm{NiCl}_{2}$, it is possible to conclude that the acid phosphatase is a potential indicator of soil impact cause by Ni. Acid phosphatase showed a peak of activity when sewage sludge was contaminated with 502 (first sampling) or $329 \mathrm{mg} \mathrm{kg}^{-1} \mathrm{Ni}$ (second sampling). This suggests that a Ni-concentration in sewage sludge of 329 $\mathrm{mg} \mathrm{kg}^{-1}$ can cause impact to the soil when estimated by acid phosphatase activity, a value that is very close to the limit of $420 \mathrm{mg} \mathrm{kg}^{-1}$ established by CETESB (1999). Moreno et al. (2003a) observed a decrease in soil acid phosphatase activity when the concentration of soil Ni increased, concluding that this enzyme was the most sensitive to detect soil contamination by this heavy metal.

Soil alkaline phosphatase at the first sampling showed a drastic decrease in activity when sewage sludge containing $329 \mathrm{mg} \mathrm{kg}^{-1} \mathrm{Ni}$ was added to the
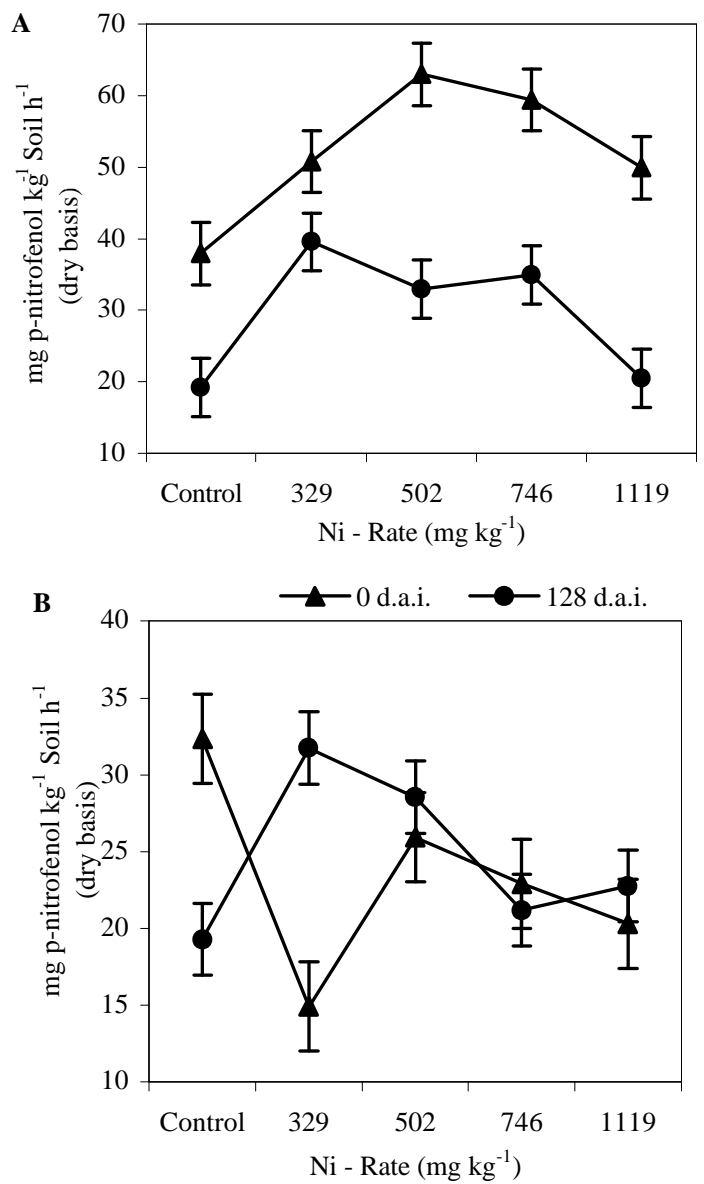

Figure 6 - Acid phosphatase (A) and alkaline phosphatase (B) in a Typic Haplustox (standard errors shown) submitted to five treatments (control plus four rates of Ni-sewage sludge) at 0 and 128 d.a.i. (days after the experiment was installed). soil, but an increase in sewage sludge Ni content by the addition of $\mathrm{NiCl}_{2}$ to the waste partially recuperated the soil enzyme activity, which decreased by the addition of higher rates of the salt. (Figure 6B). At the second sampling, the behavior of the enzyme was contrasted in relation to the first one, with the addition of a sewage sludge containing $329 \mathrm{mg} \mathrm{kg}^{-1}$ causing an increase in the enzyme activity, which decreased with the contamination of the residue with increasing rates of $\mathrm{NiCl}_{2}$. In general soil enzyme activity at the end of the experiment was higher when sewage sludge was added to the soil, contaminated or not with $\mathrm{NiCl}_{2}$. Similarly, Kuperman \& Carreiro (1997) also found a reduction in the activity of the enzyme alkaline phosphatase. Andrade \& Silveira (2004) also reported reduction in the alkaline phosphatase activity when the soil concentration of heavy metal increased. A negative correlation between alkaline phosphatase activity and "total" (USEPA, 1986) and extractable soil $\mathrm{Ni}$ was found at the end of the experiment (Table 1).

\section{CONCLUSIONS}

Sewage sludge pre-contaminated with nickel increased the soil content of "total" (USEPA, 1986) and extractable (Mehlich 1) Ni. The soil microbial biomass- $\mathrm{C}$, the $\mathrm{C} / \mathrm{N}$ ratio of the soil microbial biomass, the acid and the alkaline phosphatase activities decreased with increasing rates of $\mathrm{Ni}$ in the sewage sludge. The soil microbial $\mathrm{N}$, the $\mathrm{C} / \mathrm{N}$ ratio of the soil microbial biomass, the acid phosphatase and the alkaline phosphatase activities were good indicators for estimating soil Ni impact caused by sewage sludge application, while urease was not. A Ni concentration of $329 \mathrm{mg} \mathrm{kg}^{-1}$, which is slightly lower than the limit of $420 \mathrm{mg} \mathrm{kg}^{-1}$ established by CETESB (1999) for the use of sewage sludge in agricultural soils, caused negative effects on soil microorganisms and on soil acid and alkaline phosphatase activities.

\section{ACKNOWLEDGMENTS}

To FAPESP, for the financial support, and to CAPES, for the scholarship for the first author.

\section{REFERENCES}

ALLOWAY, B.J. (Ed.). Heavy metals in soils. Glasgow: Blackie Academic and Professional, 1995. p.153-178: Chromium and nickel.

ANDRADE, S.A.L de; SILVEIRA, A.P.D. da. Biomassa e atividade microbianas do solo sob influência de chumbo e da rizosfera da soja micorrizada. Pesquisa Agropecuária Brasileira, v.39, p.1191-1198, 2004. 
CARNEIRO, M.A.C.; MOREIRA, F.M.S.; SIQUEIRA, J.O. Atividade enzimática e biomassa microbiana em solo contaminado com metais pesados. In: CONGRESSO BRASILEIRO DE CIÊNCIA DO SOLO, 29., Ribeirão Preto, 2003. Solo: alicerce dos sistemas de produção. Ribeirão Preto: SBCA, 2003. 1 CD Rom.

CHANDER, K.; BROOKES, P.C. Residual effects of zinc, copper and nickel in sewage sludge on microbial biomass in a sandy loam. Soil Biology and Biochemistry, v.25, p.1231-1239, 1993.

CHANDER, K.; BROOKES, P.C.; HARDING, S.A. Microbial biomass dynamics following addition of metal-enriched sewage sludges to a sandy loam. Soil Biology and Biochemistry, v.27, p.1409-1421, 1995.

COMPANHIA DE TECNOLOGIA DE SANEAMENTO AMBIENTAL - CETESB. Aplicação de lodos de sistemas de tratamento biológico em áreas agrícolas - critérios para projeto e operação. São Paulo: CETESB, 1999. (Manual Técnico).

DEFELIPO, B.V.; RIBEIRO, A.C. Análise química de solo: metodologia. Viçosa: UFV, 1981. 17p. (Boletim de Extensão, 29).

EIVAZI, F.; TABATABAI, M.A. Phosphatases in soils. Soil Biology and Biochemistry, v.9, p.167-172, 1977.

GIANFREDA, L.; BOLLAG, J.M. Influence of natural and antropogenic factors on enzyme activity in soil. In: STOTZKY, G.; BOLLAG, J.M. Soil biochemistry. New York: Marcel Dekker, 1996. v.9, p.123-193.

HAIDER, J.; MURAMOTO, T.; AZAD, A. K. Estimation of microbial biomass carbon and nitrogen in Blangadesh soils. Soil Science and Plant Nutrition, v.37, p.591-599, 1991.

KUPERMAN, R.G.; CARREIRO, M.M. Soil heavy metal concentrations, microbial biomass and enzyme activities in a contaminated grassland ecosystem. Soil Biology and Biochemistry, v.29, p.179-190, 1997.

MALAVOLTA, E.; MORAES, M.F. de; LAVRES JR., J.; MALAVOLTA, M. Micronutrientes e metais pesados essencialidade e toxidez. In: PATERNIANI, E. (Org.). Ciência, agricultura e sociedade. 1.ed. Brasília - DF: Embrapa, 2006. v.1, p.117-154.

MAY, P.B.; DOUGLAS, L.A. Assay for soil urease activity. Plant and Soil, v.45, p.301-305, 1976.
MELO, G.M.P.; MELO, V.P.; MELO, W.J. Metais pesados no ambiente decorrente da aplicação de lodo de esgoto em solo agrícola. In: BRASIL. Ministério do Meio Ambiente. Conselho Nacional do Meio Ambiente. Processos. Brasília: MMA, CONAMA, 2004. 98p. Available in: <http://www.mma.gov.br/ port/conama/processos/CB5F6214/LODOMETAL.pdf>. Accessed in: 29 Jun. 2004.

MELO, W.J.; MELO, G.M.P.; BERTIPAGLIA, M.A.; MELO, V.P. Experimentação sob condições controladas. Jaboticabal: FUNEP, 1998. 86p.

MORENO, J.L.; GARCÍA, C.; HERNÁNDEZ, T. Toxic effect of cadmium and nickel on soil enzymes and the influence of adding sewage sludge. European Journal of Soil Science, v.54, p.377-386, 2003a.

MORENO, J.L.; PÉREZ, A.; ALIAGA, A.; HERNÁNDEZ, T. The ecological dose of nickel in a semiarid soil amended with sewage related to the unamended soil. Water, Air and Soil Pollution, v.143, p.289-300, 2003b.

NANNPIERI, P. The potential use of soil enzymes as indicators of productivity, sustainability and pollution. In: PANKHURST, C.E.; DOUBE, B.M.; GUPTA, V.V.S.R.; GRACE, P.R. (Ed.). Soil biota management in sustainable farming systems. Melbourne: CSIRO, 1994. p.238-244.

RAIJ, B. van; QUAGGIO, J.A.; CANTARELLA, H.; FERREIRA, M.E.; LOPES, AS.; BATAGLIA, O.C. Análise química do solo para fins de fertilidade. Campinas: Fundação Cargill, 1987.

USEPA Standards for the use and disposal of sewage sludge. Washington: EPA, 1986. (Code of Federal Regulations 40 CRF Part 503).

VANCE, E.D.; BROOKES, P.C.; JENKINSON, D.S. An extraction method for measurement soil microbial biomass-C. Soil Biology and Biochemistry, v.19, p.703-707, 1987.

WELP, G.; BRÜMMER, G.W. Toxicity of increased amounts of chemicals and the dose-response curves for heterogeneous microbial populations in soil. Ecotoxicology and Environmental Safety, v.37, p.37-44, 1997.

Received July 22, 2005

Accepted January 10, 2007 